\title{
PILIHAN RASIONAL KEPUTUSAN PEREMPUAN SARJANA MENJADI IBU RUMAH TANGGA
}

\author{
Ardina Wulantami \\ Departemen Sosiologi Universitas Indonesia \\ Email : ardinawulantami@gmail.com
}

\begin{abstract}
Abstrak
Di tengah semakin tingginya jumlah perempuan masuk ke ranah publik, muncul fenomena arus balik, yakni perempuan yang memilih berkarir sebagai ibu rumah tangga meski mereka telah mencapai gelar sarjana. Berbagai kajian menunjukkan bahwa keputusan perempuan menjadi ibu rumah tangga lebih didasarkan pada alasan kecukupan ekonomi, pengasuhan anak, dan atau tuntutan suami. Rasionalitas seringkali hanya dilekatkan pada perempuan berpendidikan tinggi yang menjadi wanita karir atau bekerja di sektor publik. Namun pada artikel ini membahas rasionalitas pilihan sarjana perempuan menjadi ibu rumah tangga, dengan menganalisis keputusan mereka berbasis perhitungan cost and reward serta Comparison Alternative (CA, Artikel ini mengulas keputusan perempuan bergelar sarjana menjadi ibu rumah tangga sebagai pilihan rasional. Kasus yang dipaparkan dikaji melalui metode kualitatif (wawancara mendalam dan observasi) terhadap empat perempuan sarjana yang memutuskan menjadi ibu rumah tangga.
\end{abstract}

Kata kunci : pilihan rasional, cost, reward, educated housewife, comparison level, comparison alternative

\begin{abstract}
While of increasing women to choose participating in public sphere as there is a greater chance of education and job opporunity. However, there is an indication that some women tend to work as housewives although they have earned a higher degree of education. In previous researches, women chose to become housewife because of economical sufficiency, children and also husband. Higher rationality is usually regards that women with higher education could attain career or work in the public sector. But, the purpose of this research is to describe the rationality of female graduates who chose to work as housewives. By analizing the cost and rewards which is accompanied by comparison alternative (CA) analysis, this research explains the rational choice of female graduates who later work as housewives. The method in this research uses qualitative approach, having in-depth interview and observation towards four housewives whom are bachelor graduates.

Keywords : rational choice, cost, reward, educated housewife, comparison level, comparison alternative
\end{abstract}

\section{Pendahuluan}

Pada umumnya, fungsi keluarga, yang sesuai dengan norma dan nilai di masyarakat, memiliki komposisi laki-laki sebagai ayah yang berperan sebagai 
pencari nafkah, dan perempuan sebagai ibu rumah tangga. Artinya, ada pembagian peran dalam keluarga yakni laki-laki sebagai pencari nafkah di ranah publik sedangkan perempuan mengurus rumah tangga di ranah domestik. Dikotomi peran ini pun tertuang dalam UU Perkawinan no 1 tahun 1974 pasal 31 bahwa Laki-laki sebagai kepala keluarga, perempuan sebagai Ibu rumah tangga. Pembagian peran tersebut dianggap lumrah dan wajar di masyarakat luas, termasuk anggapan bahwa perempuan sebagai ibu rumah tangga diposisikan subordinat karena ada ketegantungan pada suami/lakilaki sebagai kepala keluarga sekaligus pencari nafkah (utama).ada dasarnya kiprah perempuan di ranah publik bukanlah fenomena baru, khususnya di masyarakat agraris. Berdasarkan Survey Angkatan kerja nasional jumlah partisipasi angkatan kerja perempuan mengalami penurunan dalam kurun waktu tiga tahun terakhir. pada tahun 2011, presentase perempuan yang bekerja mencapai $52.44 \%$, dan hingga tahun 2013 menjadi $50.28 \%$ (http://www.bps.go.id/kependudukan/ Pages/DataSurvey/Sakernas/Ekono mi_dan_Ketenagakerjaan/TPAK/Nasi onal.aspx). Hal ini telah berbalik pada fenomena yang terjadi di tahun-tahun sebelumnya dimana presentase partisipasi kerja perempuan mengalami kenaikan yaitu pada tahun 2006-2008, Tingkat Partisipasi Angkatan Kerja perempuan mengalami kenaikan yaitu dari 48.3 \% hingga $51.25 \%$. Presentase perempuan yang bekerja memang mengalami penurunan namun hal ini belum mengindikasikan menyebabkan jumlah perempuan sebagai ibu rumah tangga. Berdasarkan hasil statistik tahun 2012, presentase perempuan yang mengurus rumah tangga sebesar 36.97 persen.

Keputusan perempuan menjadi ibu rumah tangga telah menjadi fenomena di berbagai negara. Di Amerika, dalam penelitian Pew Research Centre (menunjukkan telah terjadi kenaikan proporsi ibu rumah tangga yang pada tahun 2012 mencapai 29\% , padahal tahun 2008 hanya $26 \%$. Artinya ada kenaikan 3 $\%$, Hal serupa juga terjadi di Singapura, partisipasi perempuan di dunia kerja relatif lebih rendah padahal setengah dari penduduk sarjana adalah perempuan. Demikian juga di Jordania, Lebanon, dan Syria. Hasil penelitian 
menyatakan bahwa presentase dan biaya perawatan anak (35\%) perempuan yang meninggalkan (The Working Mother Research karirnya mencapai lebih dari $75 \%$. Institute Report, 2011) Sementara (Haque,2000)

Pilihan perempuan melepaskan Miller dalam artikelnya berpandangan bahwa perempuan yang karir pekerjaannya, dan memilih memutuskan untuk menjadi ibu menjadi ibu rumah tangga, pada rumah tangga lebih didorong oleh dasarnya bisa dilatari berbagai faktor. keinginan untuk mengatur kehidupan Studi Watanabe (2007) pilihan menjadi ibu rumah tangga penuh waktu di Jepang dipengaruhi oleh tingkat pendidikan suami. Watanabe berargumen bahwa semakin tinggi latar belakang pendidikan suami, perempuan cenderung /terhambat untuk kembali ke tempat kerja. Salah satu faktornya adalah kultur masyarakat Jepang yang menanamkan -nilai bahwa pria harus bekerja dan wanita tinggal di rumah. Sementara studi lain di Norwegia dari Ronsen dan Kitterod (2011) mengungkap bahwa faktor lebih tingginya penghasilan suami daripada istri menjadi alasan bagi perempuan untuk memilih menjadi ibu rumah tangga saja

Temuan lainnya yang dilakukan melalui Survey Internasional di New York tahun 2011, mengungkap alasan utama perempuan meninggalkan karirnya dan menjadi ibu rumah tangga adalah karena kebutuhan anak (44\%) anaknya sendiri dan juga menghabiskan waktu bersama anakanaknya (Miller,2013). Temuan serupa juga didapat Giele dari penelitiannya bahwa pada kalangan ibu rumah tangga kelas menengah di Amerika juga lebih memilih menjadi ibu rumah tangga karena bertekad untuk mendedikasikan dirinya pada anak-anaknya demi tumbuh kembang anak-anaknya. Namun Giele menambahkan adanya faktor ketidakpercayaan atau kewaspadaan terhadap bantuan dari pihak lain seperti: asisten rumah tangga atau baby sitter yang juga memperkuat keputusan perempuan menjadi ibu rumah tangga (Giele,2008).

Dari berbagai studi diatas, umumnya lebih berfokus pada faktorfaktor eksternal yang mendasari keputusan perempuan berpendidikan tinggi menjadi ibu rumah tangga, misalnya: anak, suami, serta nilai masyarakat. Kajian ini lebih berfokus pada faktor 'internal' tentang proses 
perempuan terdidik mengalami 'pasang surut' dalam dirinya sebelum memutuskan menjadi ibu rumahtangga. Pertanyaan kritisnya adalah apakah keputusan perempuan bergelar sarjana menjadi ibu rumah tangga merupakan suatu 'keterpaksaan' atau sebagai 'pilihan'. Artinya keputusan perempuan bergelar sarjana untuk menjadi ibu rumah tangga merupakan pilihan rasional dengan mempertimbangkan cost and reward.

\section{Metode}

Penelitian ini menggunakan pendekatan kualitatif karena bertujuan menggali pengalaman perempuan berpendidikan tinggi dalam memutuskan diri menjadi iburumahtangga, bukan menjadi perempuan karir sebagaimana perempuan sarjana lainnya. Sebab itu, studi ini tergolong studi kasus karena mengungkap proses pengambilan keputusan yang terjadi pada perempuan sarjana, termasuk alasan-alasan mereka di saat memutuskan hanya berstatus sebagai ibu Rumahtangga. Empat Kasus dalam studi ini adalah perempuan yang berkarakteristik sebagai berikut: bergelar minimal sarjana strata 1 (S1), dan telah

meninggalkam karirnya untuk menjadi ibu rumah tangga penuh waktu.Pengumpulan data digali dalam kurun waktu selama satu bulan melalui wawancara mendalam dan observasi

Empat perempuan yang menjadi kasus adalah: VT, berusia 29 tahun, Sarjana Komunikasi Iulusan Universitas Indonesia. VT telah menikah 2 tahun, dan sudah memutuskan berstatus menjadi ibu rumah tangga saja selama 1 tahun. Suami VT bekerja sebagai Process Integrator di sebuah perusahaan swasta. Pasangan ini tinggal di pinggiran perkotaan.

Kasus kedua, DP, berusia 30 tahun, merupakan lulusan Universitas Gunadarma. DP sudah menikah 5 tahun, dan masuki tahun ke-2 perkawinannya ia memutuskan menjadi ibu rumah tangga, Suami DP, 32 tahun bekerja sebagai trainer di bidang UMKM. Adapun sebaga kasus ke-3 RT berusia 30 tahun. Pendidikannya sarjana Farmasi dari Universitas Indonesia dan sudah, menjalani sebagai ibu rumah tangga penuh waktu selama dua tahun. RT bersama suami dan anaknya yang berusia 2 tahun tinggal di suatu perumahan di pinggiran perkotaan. Suami RT, berusia 32 tahun bekerja 
sebagai IT officer di sebuah Rumah Sakit swasta Jakarta Dan kasus keempat, AG berusia 32 tahun merupakan lulusan Universitas Diponegoro dan sudah menjalani sebagai ibu rumah tangga selama enam tahun. Suami AG bekerja sebagai PNS di Kementrian ESDM. Saat ini AG beserta suami dan anak perempuannya berusia 5 tahun tinggal di pinggiran Kota

\section{Hasil dan Pembahasan}

Teori pilihan rasional berasumsi dasar bahwa pengambilan keputusan individu dengan unit dasar analisis dalam relasi sosial dan aktor yang menjadi fokus utama dalam teori ini. Aktor dipandang memiliki preferensi atau nilai, kepuasan. (Ritzer, 2008). Menurut Homans dalam (Ritzer, 2008) pilihan rasional terkait dengan kalkulasi seseorang dalam berbagai tindakan alternatif yang tersedia baginya. Mereka membandingkan jumlah imbalan yang bernilai tinggi dengan yang bernilai rendah. Imbalan yang paling diinginkan adalah imbalan yang sangat bernilai dan sangat mungkin tercapai. Dalam proporsi rasionalitas, Homans mengaitkan dengan keberhasilan, stimulus, dan proposisi nilai.
Menurut Friedman dan Hechter dalam (Ritzer,2008), teori pilihan rasional memang berangkat dari tujuan atau maksud aktor akan tetapi terdapat pertimbangan atau hambatan utama dalam melakukan tindakan, yaitu : kelangkaan sumber daya dan institusi sosial. Kelangkaan sumber daya berkaitan dengan biaya yang dikeluarkan dalam mencapai tujuan. Masing-masing aktor memiliki sumber daya berbeda. Dan perbedaan ini berimplikasi pada perbedaan akses dalam mencapai tujuan. Sedangkan yang kedua adalah, institusi sosial. Friedman dan Hechter dalam (Ritzer,2008) mengungkapkan bahwa pada umumnya individu akan dikendalikan oleh aturan keluarga dan sekolah; hukum dan organisasi; gereja dan masjid. Artinya dalam pilihan aktor tetap dikendalikan oleh norma dalam masyarakat.

Teori pilihan rasional di dalam keluarga yang dijelaskan oleh Coleman memaparkan pilihan rasional sebagai tindakan manusia dalam memaksimalkan kepuasan yang ingin dicapai. Dan untuk mengerti apakah pilihan aktor merupakan rasional, perlu diketahui apa yang menjadi keuntungan/ rewarding dan beban/ cost. (White 
and Klein, 2002) Teori pilihan rasional memiliki proposisi diantaranya : pertama, methodological individualism yang berimplikasi bahwa fenomena kelompok, struktur sosial dikonstruksi oleh tindakan individu. Dan pada dasarnya tindakan individu akan merujuk pada keuntungan yang paling besar. Yang kedua adalah penjelasan rasional datang dari motivasi aktor. Dalam pilihan individu, terdapat kendala-kendala yang dihadapi akan tetapi aktor akan memilih pilihan yang lebih menguntungkan.

Teori pilihan rasional dari Coleman bergerak dari individu sebagai aktor ke tingkat masyarakat. Oleh karena itu penjelasan Coleman tentang pilihan rasional melibatkan norma dan human capital. Coleman menyebutkan bahwa pilihan individu dipengaruhi oleh sistem norma dimana norma yang muncul berasal dari tindakan yang dilakukan sejumlah orang atau tidak adanya aktor yang mengatur perilaku. White and Klein mendefinisikan reward sebagai apapun yang diterima seseorang sebagai keuntungan. Sedangkan cost secara sederhana merupakan kebalikan dari reward. Klein mendefinisikannya sebagai
"Negative rewards the opportunities for rewards that might be missed or foregone that are associated with any specific choice. (White and Klein,2002)

Atau diartikan sebagai kebalikannya dari rewards atau sesuatu yang dianggap tidak memberikan keuntungan untuk pemenuhan self-interest aktor. Dalam pemaparan melalui teori rational choice, White dan Klein (2002) mengajukan konsep Comparison Level (CL) dan Comparison Alternative $(\mathrm{CL}+)$. Comparison level merupakan perbandingan atas apa yang akan diperoleh individu (aktor) dengan orang lain yang berada diposisi sama dengannya dan bagaimana kondisi aktor/individu tersebut jika dibandingkan dengan orang lain . Sedangkan Comparison Alternative $\quad(\mathrm{CL}+) \quad$ adalah perbandingan antara individu/aktor dengan orang lain yang berada di posisi berbeda dengan individu/aktor tersebut (White and Klein, 2002:38). Dalam artikel ini dijelaskan bagaimana perempuan sarjana yang menjadi lbu rumah tangga membandingkan dirinya dengan perempuan sarjana lain yang memilih untuk bekerja di ranah publik dan menjalankan peran ganda. 
Berstatus sebagai ibu rumah tangga penuh waktu bagi perempuan bergelar sarjana seringkali menjadi hal yang dilematis. Hal ini mengingat ada stigma bahwa perempuanperempuan tersebut bersikap tidak rasional ketika hanya memilih berstatus sebagai ibu rumahtangga penuh waktu. Temuan studi menunjukkan bahwa ada perbedaan pemaknaan di kalangan perempuan bergelar sarjana atas keputusan mereka sebagai ibu rumah tangga penuh waktu, Untuk kasus VT yang telah satu tahun tiga bulan menjadi ibu rumah tangga penuh waktu, mengungkapkan keputusannya merupakan sebuah pilihan dan bukanlah pemberian atau takdir yang tidak bisa dielakkan. Artinya, bagi VT tidak ada masalah jika ada perempuan yang hanya menjadi ibu rumah tangga karena lebih mengedepankan pentingnya kehadiran ibu pada fase emas perkembangan anak, yakni membentuk fondasi yang baik dan kuat. VT juga tidak merasa menyesal akan pendidikan yang telah dicapainya, dengan keputusannya sekarang ia merasa sangat menikmati mendampingi tumbuh kembang anak.
Sementara DP, 30 tahun, yang telah menjadi ibu rumah tangga penuh waktu selama empat tahun memaparkan bahwa pilihan menjadi ibu rumah tangga dimaknai sebagai bentuk tanggung jawab kepada suami dan anak. Informan tersebut sepakat pada nilai yang diyakini masyarakat pada umumnya bahwa suami yang bertugas menafkahi keluarga dan tugas istri adalah mengurus rumah tangga. Hal ini menjadi suatu nilai yang diyakini DP dan suaminya karena mereka tidak mau mempercayakan anak mereka pada tenaga luar atau Asisten rumah tangga.

Tidak berbeda dengan VT dan DP, informan RT, sarjana farmasi yang telah 2 tahun menjadi ibu rumah tangga, mengaku bahwa keputusan untuk bisa mendidik anak secara full time diputuskannya pada saat ia sedang mengandung anak pertamanya. Faktor yang melatari keputusannya adalah kondisi pekerjaan RT sebagai Apoteker di Rumah Sakit yang harus melayani penjualan obat sehingga ia harus sering berdiri dan berhadapan dengan orang sakit. Hal ini tidak memungkinkan dilakukan jika RT hamil. la mengatakan bahwa peran sebagai ibu rumah tangga tidak 
terbeli oleh apapun, ia merasa puas dapat mengurus anaknya sendiri. bahwa terdapat pemaknaan atas pilihannya sebagai rumah tangga disamping pencapaian gelar sarjananya.

Berpijak pada berbagai alasan informan, terungkap. Informan VT, RT, bahkan DP merepresentasikan bahwa sebuah keputusan menjadi ibu rumah tangga terkait dengan pereferensinya sendiri dan seirama dengan pernyataan Ritzer (2008) bahwa pilihan rasional merupakan pilihan individu yang dimotivasi oleh tindakan aktor yang dipandang memiliki preferensi dan tujuan .

Pernyataan informan RT bahwa peran sebagai ibu rumah tangga tidak terbeli oleh apapun dan ia merasa puas dapat mengurus anak sendiri seturut dengan apa yang disampaikan Coleman (White,Klein, 2002) bahwa tindakan individu akan mengarah pada keuntungan dan kepuasan yang lebih besar.

Dalam pengambilan keputusan sebagai ibu rumah tangga penuh waktu, suami VT dan DP menjadi inisiator dalam keputusan tersebut. Kedua suami informan menganggap bahwa seorang anak lebih baik diasuh oleh orang tuanya bukan tenaga baby sitter atau asisten rumah tangga. proses pengambilan keputusan pasangan DP telah terjadi sebelum pernikahan sedangkan VT dan pasangannya baru memutuskan semenjak anak VT lahir. Sedangkan informan $R T$, dalam pengambilan keputusannya juga terdapat sosialisasi dari peran mertuanya, yang memberi dukungan kepada menantunya, RT untuk menjadi Ibu rumah tangga penuh waktu hal ini dianggap karena pekerjaan sebagai Ibu rumah tangga merupakan ibadah dan besar pahalanya. RT pun juga sepakat bahwa dalam agama, mengurus anak dan suami itu wajib dan akan mendapat pahalanya yang besar.

Pada kasus keempat yaitu AG, keputusan menjadi ibu rumah tangga diawali karena ia tidak mendapatkan pekerjaan sebagai Pegawai Negri Sipil, sehingga AG menganggap bahwa perannya sebagai Ibu Rumah Tangga merupakan nasib yang harus dijalankan. Pada awalnya ia tidak hanya bernegoisasi kepada suaminya tetapi juga pada orang tuanya karena latar belakang pekerjaan orang tua $A G$ adalah Pegawai Negri Sipil sehingga AG diharapkan tidak hanya menjadi ibu rumah tangga tetapi juga bekerja di ranah publik. Semenjak berpindah 
rumah ke Jakarta, AG memutuskan menjadi Ibu rumah tangga penuh waktu dan ia mengaku tidak pernah menyesal menjadi lbu rumah tangga apalagi dengan kehadiran anak perempuannya.

Berdasarkan keempat informan dapat dikatakan bahwa pilihan menjadi ibu rumah tangga tetap dapat dikatakan sebagai pilihan rasional karena terdapat motivasi dan preferensi dari para aktor walaupun dipengaruhi oleh aktor lain yaitu anak dan suami lbu rumah tangga memiliki preferensi untuk mengasuh dan merawat anaknya sendiri dan memiliki preferensi untuk mengikuti nilai masyarakat atas keluarga konvensional. Hal ini sesuai dengan apa yang dikemukakan oleh Friedman dan Hechter dalam (Ritzer,2008) bahwa pilihan individu tidak terlepas dari aturan-aturan yang ada pada masyarakat seperti aturan keluarga.

Peran sebagai Ibu Rumah Tangga yang dijalani oleh perempuan bergelar sarjana dirasa menjadi pilihan individual dan dapat dilihat dengan analisis comparison level (CL). Comparison level merupakan perbandingan atas apa yang diperoleh orang lain yang berada di posisi sama, dan bagaimana kondisi individu yang bersangkutan jika dibandingkan dengan orang tersebut (White dan Klein,2000). Dalam studi ini, ibu rumah tangga yang berpendidikan tinggi dalam penelitian ini membandingkan posisinya dengan orang lain, yaitu ibu rumah tangga lainnya yang tidak berpendidikan tinggi. Menurut informan apa yang didapatkan sebagai ibu rumah tangga yang telah bergelar sarjana berbeda dengan apa yang didapatkan oleh ibu rumah tangga yang tidak bergelar sarjana atau hanya berpendidikan setingkat SMA atau dibawahnya.

Sebagai lbu rumah tangga yang berpendidikan tinggi, informan AG menceritakan perbedaannya dengan ibu rumah tangga yang tidak berpendidikan tinggi, ia menuturkan bahwa dengan berbekal ilmu komunikasi yang ia miliki, AG dapat mengaplikasikannya pada saat kegiatan di sekolah anaknya, kemampuan yang dimiliki $A G$ dalam berkreativitas tidak dimiliki oleh ibu rumah tangga lain. Sedangkan informan VT, menganggap bahwa nilai lebih yang dimiliki oleh dirinya sebagai ibu rumah tangga berpendidikan tinggi adalah VT memiliki sense of awareness terhadap tayangan media untuk anak. 
Bagi keempat kasus baik AG, VT, RT, DP merasa bahwa seorang perempuan entah akan berkarir atau menjadi ibu rumah tangga haruslah memiliki pendidikan yang tinggi karena seorang perempuan juga turut berperan dalam mencerdaskan anakanaknya. Seperti yang disampaikan dalam wawancara bersama AG "iyalah mau jadi ibu rumah tangga juga seorang perempuan harus sekolah tinggi dong, harus pinter kalo gak pinter gimana mau ngajarin anaknya" (AG, 5 januari 2016). AG mengungkapkan ia tetap memiliki kelebihan dibandingkan dengan ibu rumah tangga lainnya yang tidak memiliki pendidikan tinggi, la menganggap bahwa ibu rumah tangga yang telah berkuliah akan mampu memberikan pandangan dan visi kepada anaknya dalam memilih pendidikan tinggi yang terbaik, la juga merasa bisa menjadi role model bagi anaknya. Hal ini diungkapkan karena berdasarkan perbandingannya terhadap orang tua temannya yang tidak bersekolah dengan orang tuanya sendiri yang merupakan Iulusan Universitas Negeri. Sebelum masuk ke perguruan tinggi, AG disosialisasikan oleh ibunya untuk berada di perguruan tinggi negeri sedangkan temannya tidak mendapatkan sosialisasi dari ibunya karena ibunya kurang memiliki pengetahuan yang mumpuni tentang kuliah.

Serupa juga yang dialami oleh VT, dan DP. Mereka merasakan perbedaannya antara ibu rumah tangga yang berpendidikan tinggi dengan yang tidak memiliki pendidikan tinggi berlandaskan dari pengalaman dalam keluarganya terdahulu. Orang tua mereka hanyalah lulusan SMA, sehingga ketika VT dan DP beranjak ke bangku kuliah, ia tidak mendapatkan sosialisasi mengenai perguruan tinggi dari ibu mereka yang merupakan orang tua terdekat mereka sebagai agen sosialisasi primer, hal ini berimplikasi kepada mereka yang tidak memiliki role model dan harus mencari informasi sendiri. Dalam kasus DP juga ditemukan perbandingan antara ibu rumah tangga yang berpendidikan tinggi dan ibu rumah tangga yang tidak berpendidikan tinggi. DP mengungkapkan bahwa terdapat tetangganya yang merupakan lulusan SMP, terlihat tidak serius dalam mendidik dan mengurus anaknya. la tidak menanamkan pentingnya pendidikan sehingga anaknya yang tidak mau bersekolah, dibiarkan tidak 
bersekolah. Berbeda dengan DP yang telah merancang pendidikan untuk anaknya hingga pendidikan tinggi. hal ini didasari oleh DP yang telah memiliki intelektualitas dibandingkan tetangganya. Meskipun pola pengasuhan anak tidak hanya dipengaruhi oleh pendidikan orang tua, tidak dapat dipungkiri bahwa intelektualitas perempuan dipengaruhi oleh pendidikannya.

Sedangkan dalam kasus RT, nilai lebih yang didapatkan sebagai ibu rumah tangga berpendidikan tinggi diperoleh karena ilmu farmasi yang didapatkan di perguruan tinggi, RT mengungkapkan bahwa ilmu yang dipelajari saat kuliah tidak menjadi sia-sia karena hingga saat ini ia masih mengaplikasikan ilmu yang dipelajari dalam keluarganya, seperti ketika anaknya dan anggota keluarganya sedang sakit, RT dapat mengetahui obat apa yang sesuai, terkhusus untuk anaknya. RT tidak cepat terlalu bergantung pada tenaga ahli medis. berdasarkan keempat kasus dinyatakan bahwa dalam perbandingan menggunakan analisa comparison level, Ibu rumah tangga berpendidikan tinggi memiliki nilai lebih dibandingkan ibu rumah tangga yang tidak berpendidikan tinggi dalam aspek pola pengasuhan anak, dan internalisasi pendidikan serta nilai lebih dalam aplikasinya di bidang ilmu semasa kuliah.

Berdasarkan wawancara dengan informan, keempatnya masih sering berkomunikasi dan saling berbagi cerita dengan temantemannya yang juga ibu rumah tangga. Seperti yang disampaikan oleh informan RT meskipun tidak lagi memiliki rekan kerja seperti saat bekerja dulu, namun ia tidak merasa kesepian. "Hmm kesepian, enggak sih. Di lingkungan rumah ini kan juga rame. Ada banyak ibu-ibu yang jadi ibu rumah tangga." (Wawancara dengan RT, 27 Oktober 2015)

Informan VT juga memaparkan bahwa sampai sekarang, ia masih rajin chatting dengan teman kantornya dan masih sering bertemu dalam acara-acara pernikahan teman. Meski lingkungan pergaulannya lebih terbatas di komunitas rumah tinggalnya, namun. keempat informan merasa memiliki kesamaan, dan menganggap apa yang mereka dapatkan tidak jauh berbeda dengan teman-temannya yang juga menjadi ibu rumah tangga memiliki nilai tambah sebagai Ibu rumah tangga yang berpendidikan tinggi, karena mereka dapat mengaplikasikan ilmu yang dipelajari 
di kuliah dalam pembelajaran anaknya.

Pekerjaan domestik seringkali dilekatkan pada perempuan, dan pada saat memutuskan menjadi ibu rumah tangga penuh waktu, maka secara otomatis beban pekerjaan domestik menjadi tanggung jawab penuh perempuan. Hasil studi menunjukkan pada kenyataannya tidak selalu demikian. Ada negoisasi dalam keluarga, seperti yang terjadi pada informan VT bahwa dalam keluarganya terdapat kesepakatan sewaktu awal pernikahan bahwa suami juga turut ambil bagian dalam melakukan pekerjaan domestik.

"So far sih dari dulu nikah, dia slalu bantuin cuci piring itu udah inisiatif, kadang kalau sabtu dia juga bantuin nyapu, ngepel,beresin mainan anak, gak harus aku yang ngerjain tugas rumah tangga sepenuhnya" (wawancara dengan VT, 22 Oktober 2015)

Demikian juga dengan informan

AG yang menuturkan bahwa dalam keluarganya, suami AG juga masih bersedia melakukan pekerjaan rumah tangga seperti mencuci baju, membereskan mainan anak, mencuci kendaraan. Hal tersebut telah disepakati AG dan pasangannya sewaktu awal pernikahan.

Hal ini mengkonfirmasi penelitian Febrini dalam
(Anggraini,2012) bahwa telah terjadi pergeseran nilai budaya terhadap pembagian kerja laki-laki dan perempuan dimana laki-laki mulai melakukan pekerjaan domestik.

Keputusan sarjana perempuan menjadi ibu rumah tangga jika dilihat dengan analisa comparison level for alternatives $(\mathrm{CL}+)$ Ibu rumah tangga bergelar sarjana membandingkan perannya yang mereka jalani dengan para ibu yang bekerja dan menjalani peran ganda. Ketiga informan menyadari bahwa ketika perempuan memutuskan untuk menjadi wanita karir, frekuensi pertemuan dengan anak lebih rendah sehingga intensitas kedekatan relasi dengan anak juga rendah. Hal ini tentunya berimplikasi pada perkembangan anak. mengkonfirmasi temuan Hoffman dalam (Goodde,1995) yang menuliskan bahwa anak-anak dari ibu yang bekerja menunjukkan kemampuan yang lebih rendah dan cenderung menghadapi persoalan yang sulit dengan sikap tidak dapat menyesuaikan diri. Pada kalangan wanita karir yang menjalani peran ganda, umumnya memerlukan tenaga untuk membantu mengasuh anak. Sementara di sisi lain justru ada kewaspadaan terhadap baby sitter atau pengasuh anak. Informan 
RT mengungkapkan bahwa ia merasa beruntung bisa mengasuh anak sendiri karena banyak temantemannya yang bekerja mengalami kesulitan mencari asisten/pembantu dan ia juga banyak mendengar bahwa anak-anak teman-temannya tersebut mendapat perlakuan yang tidak baik dari pembantu rumah tangga. Informan AG pun memaparkan bahwa ia merasa aman bisa mengasuh anaknya sendiri karena melihat tayangan di media mengenai kasus kekerasan dan penyimpangan anak Sedangkan DP mengungkapkan bahwa di samping ia tidak bisa percaya dengan jasa baby sitter terdapat juga perhitungan ekonomi, yang menurut informan pengeluaran rumah tangganya akan menjadi tinggi jika harus menggunakan jasa pembantu rumah tangga.

Dengan demikian, alasan efektifitas pengasuhan anak dan penghematan biaya ekonomi menjadi dasar perempuan bergelar sarjana memutuskan diri hanya berstatus sebagai ibu rumah tangga penuh waktu atau bekerja kembali untuk urusan domestik. Serupa dengan pernyataan White dan Klein bahwa pilihan aktor didasarkan pada pertimbangan keuntungan/ reward dan besarnya cost. Dengan melakukan perbandingan terhadap situasi dari aktor lain yang berbeda, keputusan perempuan sarjana menjadi ibu rumah tangga dimaknai sebagai sebuah pilihan rasional.

Dalam mengkaji apakah keputusan yang diambil oleh perempuan sarjana merupakan sebuah pilihan rasional, maka perlu dideskripsikan mengenai pilihanpilihan alternatif yang dihadapkan perempuan sarjana dalam memutuskan pilihannya sebagai Ibu Rumah Tangga. Sebagai perempuan yang telah mencapai pendidikan tinggi, mereka memiliki kesempatan untuk berkarya di ranah publik. Informan VT menceritakan bahwa ia sempat bekerja di Perusahaan Sampoerna Foundation dengan jabatan yang cukup mapan. la juga sempat diberikan tawaran berbagai pekerjaan dengan gaji yang lebih dari cukup. Akan tetapi pilihannya tetap pada mengurus rumah tangga penuh waktu. Sebagai ibu rumah tangga yang terbilang masih berusia muda, mereka juga memiliki berbagai pilihan alternatif seperti bekerja paruh waktu, berwirausaha sendiri misalnya dengan berjualan di online shop atau bahkan menitipkan anak ke keluarga batih atau ke jasa day care. 
Menurut pengakuan informan, berbagai pilihan alternatif tersebut sempat terpikirkan. Akan tetapi kendalanya adalah mereka masih mencari-cari ide untuk merealisasikannya. Dalam keputusannya sebagai lbu rumah tangga penuh waktu, perempuan sarjana juga menuai kontrovesi dari aktor lain, akan tetapi ketiga informan melihat bahwa memang telah banyak terjadi fenomena yang demikian. Mereka melihat teman-teman perempuan di masa kuliah juga banyak yang memilih sebagai lbu Rumah tangga penuh waktu. Hal ini seirama dengan penjelasan Monroe mengenai teori pilihan rasional yang dihasilkan pada pertimbangan aktor dari berbagai pilihannya dan kaitannya dengan aktor lain (Monroe, 2001)

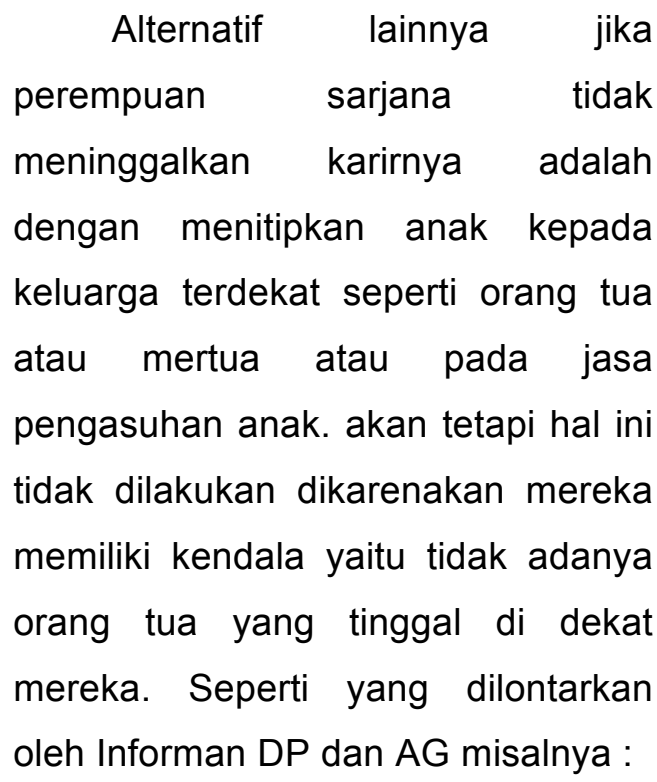

"....alesannya selain itu sudah gak ada utinya icha, jadi makin membuat kami berat untuk menitipkan icha ke baby sitter/ assisten rumah tangga karna gak ada keluarga yang mengawasi" (wawancara dengan Informan DP, 7 oktober 2015)

“.... dan menyadari kalo aku cuma bertiga di jakarta ini" (wawancara dengan informan AG, 22 oktober 2015)

Adanya kendala dalam keluarga mereka menghasilkan suatu keputusan untuk meninggalkan pekerjaan dan memilih menjadi ibu rumah tangga. Hal ini seturut dengan pilihan rasional yang dikemukakan oleh Ritzer (2008) bahwa tindakan seseorang berangkat pada adanya kelangkaan sumber daya atau perbedaan akses sumber daya lain sehingga hal ini yang akan diperhatikan aktor dalam mencapai tujuannya. Seirama juga dengan apa yang dinyatakan Coleman (dalam White \& Klein, 2002) bahwa di tengah kendala-kendala yang dihadapi aktor memilih suatu tindakan yang menguntungkan.

Tabel 1. Pengambilan Keputusan

Perempuan sarjana menjadi lbu rumah tangga

\begin{tabular}{lllll}
\hline & VT & DP & RT & AG \\
\hline Alte & $1 . M e$ & $1 . B e$ & $1 . M e$ & $1 . B e$ \\
rnati & ncari & kerja & ncari & kerja \\
f & peke & di & peke & di \\
pen & rjaan & rum & rjaan & rum \\
gam & deng & ah & yang & ah \\
bila & an & (wira & tidak & \\
\hline
\end{tabular}




\begin{tabular}{|c|c|c|c|c|}
\hline $\begin{array}{l}n \\
\text { kep } \\
\text { utus } \\
\text { an }\end{array}$ & $\begin{array}{l}\text { loka } \\
\text { si } \\
\text { yang } \\
\text { deka } \\
\text { t } \\
\text { 2.Be } \\
\text { kerja } \\
\text { di } \\
\text { rum } \\
\text { ah } \\
\text { (wira } \\
\text { swa } \\
\text { sta) }\end{array}$ & $\begin{array}{l}\text { swa } \\
\text { sta) }\end{array}$ & $\begin{array}{l}\text { beris } \\
\text { iko, } \\
\text { di } \\
\text { luar } \\
\text { Rum } \\
\text { ah } \\
\text { Sakit }\end{array}$ & $\begin{array}{l}\text { (wira } \\
\text { swa } \\
\text { sta) }\end{array}$ \\
\hline Cost & $\begin{array}{l}\text { 1.An } \\
\text { ak } \\
\text { tetap } \\
\text { haru } \\
\text { s } \\
\text { ditin } \\
\text { ggal, } \\
\text { tidak } \\
\text { ada } \\
\text { yang } \\
\text { men } \\
\text { gasu } \\
\text { h } \\
2 . P e \\
\text { ngha } \\
\text { silan } \\
\text { per } \\
\text { bula } \\
\mathrm{n} \\
\text { tidak } \\
\text { pasti } \\
\text { (tida } \\
\mathrm{k} \\
\text { secu } \\
\text { re) } \\
\text { dan } \\
\text { beris } \\
\text { iko }\end{array}$ & $\begin{array}{l}\text { 1.Be } \\
\text { rkur } \\
\text { angn } \\
\text { ya } \\
\text { wakt } \\
\text { u } \\
\text { bers } \\
\text { ama } \\
\text { anak }\end{array}$ & $\begin{array}{l}\text { 1.Ke } \\
\text { hilan } \\
\text { gan } \\
\text { mom } \\
\text { en- } \\
\text { mom } \\
\text { en } \\
\text { bers } \\
\text { ama } \\
\text { anak }\end{array}$ & $\begin{array}{l}\text { 1.Be } \\
\text { rkur } \\
\text { angn } \\
\text { ya } \\
\text { wakt } \\
\text { u } \\
\text { bers } \\
\text { ama } \\
\text { anak } \\
2 . H a \\
\text { rus } \\
\text { terus } \\
\text { mem } \\
\text { ikirk } \\
\text { an } \\
\text { ide } \\
\text { kreat } \\
\text { if } \\
\text { untu } \\
\mathrm{k} \\
\text { berbi } \\
\text { snis } \\
3 . \\
\text { Men } \\
\text { dapa } \\
\text { t } \\
\text { kelu } \\
\text { han } \\
\text { dari } \\
\text { sua } \\
\text { mi }\end{array}$ \\
\hline $\begin{array}{l}\text { Rew } \\
\text { ard }\end{array}$ & $\begin{array}{l}\text { 1.Me } \\
\text { miliki } \\
\text { peng } \\
\text { hasil } \\
\text { an } \\
2 .\end{array}$ & $\begin{array}{l}\text { 1.Me } \\
\text { miliki } \\
\text { peng } \\
\text { hasil } \\
\text { an }\end{array}$ & $\begin{array}{l}\text { 1.Me } \\
\text { ndap } \\
\text { at } \\
\text { peng } \\
\text { hasil } \\
\text { an }\end{array}$ & $\begin{array}{l}\text { 1.Me } \\
\text { ndap } \\
\text { atka } \\
\mathrm{n} \\
\text { peng } \\
\text { hasil }\end{array}$ \\
\hline
\end{tabular}

\begin{tabular}{|c|c|c|c|c|}
\hline & $\begin{array}{l}\text { Tida } \\
\mathrm{k} \\
\text { berg } \\
\text { antu } \\
\mathrm{ng} \\
\text { pada } \\
\text { sua } \\
\mathrm{mi}\end{array}$ & & etap & an \\
\hline $\begin{array}{l}\text { Alas } \\
\text { an } \\
\text { uta } \\
\text { ma } \\
\text { berh } \\
\text { enti } \\
\text { bek } \\
\text { erja } \\
\text { dan } \\
\text { men } \\
\text { jadi } \\
\text { lbu } \\
\text { rum } \\
\text { ah } \\
\text { tang } \\
\text { g } \\
\text { pen } \\
\text { uh } \\
\text { wakt } \\
\text { u }\end{array}$ & $\begin{array}{l}\text { 1.Tid } \\
\text { ak } \\
\text { ada } \\
\text { oran } \\
\text { g } \\
\text { yang } \\
\text { bisa } \\
\text { diper } \\
\text { caya } \\
\text { untu } \\
\mathrm{k} \\
\text { men } \\
\text { gasu } \\
\mathrm{h} \\
\text { anak } \\
\text { (pen } \\
\text { gasu } \\
\mathrm{h} \\
\text { yang } \\
\text { suda } \\
\mathrm{h} \\
\text { diper } \\
\text { caya } \\
\text {, men } \\
\text { gund } \\
\text { urka } \\
\mathrm{n} \\
\text { diri) }\end{array}$ & $\begin{array}{l}\text { 1.Ke } \\
\text { sepa } \\
\text { kata } \\
\mathrm{n} \\
\text { bers } \\
\text { ama } \\
\text { sua } \\
\text { mi } \\
\text { bah } \\
\text { wa } \\
\text { sua } \\
\text { mi } \\
\text { seba } \\
\text { gai } \\
\text { penc } \\
\text { ari } \\
\text { nafk } \\
\text { ah } \\
\text { dan } \\
\text { istri } \\
\text { men } \\
\text { guru } \\
\text { s } \\
\text { rum } \\
\text { ah } \\
\text { tang } \\
\text { ga }\end{array}$ & $\begin{array}{l}\text { 1.Ko } \\
\text { ndisi } \\
\text { peke } \\
\text { rjaan } \\
\text { yang } \\
\text { beris } \\
\text { iko } \\
\text { terh } \\
\text { adap } \\
\text { keha } \\
\text { mila } \\
\text { nnya }\end{array}$ & $\begin{array}{l}1 . \\
\text { Pind } \\
\text { ah } \\
\text { Loka } \\
\text { si Ke } \\
\text { Jaka } \\
\text { rta } \\
\text { (Sua } \\
\text { mi } \\
\text { berpi } \\
\text { ndah } \\
\text { tuga } \\
\text { s } \\
\text { peke } \\
\text { rjaan } \\
\text { ke } \\
\text { Jaka } \\
\text { rta) }\end{array}$ \\
\hline $\begin{array}{l}\text { Alas } \\
\text { an } \\
\text { lain } \\
\text { nya } \\
\text { Ber } \\
\text { hent } \\
\text { i } \\
\text { bek } \\
\text { erja } \\
\text { dan } \\
\text { men } \\
\text { jadi } \\
\text { Ibu }\end{array}$ & $\begin{array}{l}\text { 1.Tid } \\
\text { ak } \\
\text { taha } \\
\mathrm{n} \\
\text { deng } \\
\text { an } \\
\text { kem } \\
\text { acet } \\
\text { an } \\
\text { dala } \\
\mathrm{m} \\
\text { perja } \\
\text { lana }\end{array}$ & $\begin{array}{l}1 . I n g \\
\text { in } \\
\text { istira } \\
\text { hat } \\
\text { dari } \\
\text { beke } \\
\text { rja, } \\
\text { kare } \\
\text { na } \\
\text { suda } \\
\text { h } \\
\text { emp } \\
\text { at }\end{array}$ & $\begin{array}{l}1 . \\
\text { rasa } \\
\text { tidak } \\
\text { perc } \\
\text { aya } \\
\text { meni } \\
\text { tipka } \\
\mathrm{n} \\
\text { anak } \\
\text { kepa } \\
\text { da } \\
\text { oran } \\
\mathrm{g}\end{array}$ & $\begin{array}{l}1 . \\
\text { Tida } \\
\mathrm{k} \\
\text { diteri } \\
\text { ma } \\
\text { seba } \\
\text { gai } \\
\text { PNS } \\
2 . \\
\text { Tida } \\
\text { k } \\
\text { perc } \\
\text { aya }\end{array}$ \\
\hline
\end{tabular}




\begin{tabular}{|c|c|c|c|c|}
\hline $\begin{array}{l}\text { rum } \\
\text { ah } \\
\text { tang } \\
\text { g } \\
\text { pen } \\
\text { uh } \\
\text { wakt } \\
\text { u }\end{array}$ & $\begin{array}{l}\text { n } \\
\text { men } \\
\text { uju } \\
\text { kant } \\
\text { or } \\
\text { (loka } \\
\text { si } \\
\text { kant } \\
\text { or } \\
\text { jauh) } \\
\text { 2.Pe } \\
\text { rmint } \\
\text { aan } \\
\text { sua } \\
\text { mi, } \\
\text { sua } \\
\text { mi } \\
\text { lebih } \\
\text { sepa } \\
\text { kat } \\
\text { anak } \\
\text { diuru } \\
\text { s } \\
\text { oleh } \\
\text { oran } \\
\text { g tua } \\
\text { 3. } \\
\text { Pen } \\
\text { ghas } \\
\text { ilan } \\
\text { sua } \\
\text { mi } \\
\text { suda } \\
\text { h } \\
\text { cuku } \\
\text { p }\end{array}$ & $\begin{array}{l}\text { tahu } \\
\mathrm{n} \\
\text { beke } \\
\text { rja }\end{array}$ & $\begin{array}{l}\text { lain } \\
2 . \text { Me } \\
\text { lihat } \\
\text { ibu } \\
\text { mert } \\
\text { ua } \\
\text { seba } \\
\text { gai } \\
\text { role } \\
\text { mod } \\
\text { el } \\
\text { ibu } \\
\text { rum } \\
\text { ah } \\
\text { tang } \\
\text { ga } \\
\text { penu } \\
\text { h } \\
\text { wakt } \\
\text { u }\end{array}$ & $\begin{array}{l}\text { deng } \\
\text { an } \\
\text { jasa } \\
\text { baby } \\
\text { sitter } \\
3 . \\
\text { Tida } \\
\text { k } \\
\text { ada } \\
\text { kelu } \\
\text { arga } \\
\text { deka } \\
\text { t di } \\
\text { Jaka } \\
\text { rta }\end{array}$ \\
\hline
\end{tabular}

terwujud dalam keuntungan yang diperoleh. Maka dari itu terdapat perhitungan reward yang diperoleh dari pilihan perempuan bergelar sarjana menjadi ibu rumah tangga. Informan DP mengungkapkan bahwa hal yang didapatkan atas pilihannya menjadi ibu rumah tangga adalah dapat melihat perkembangan anak secara langsung, memberikan perhatian penuh untuk anak dan suami bahkan adik selain itu membawa perubahan bagi dirinya untuk menjadi lebih mandiri. Sedangkan informan VT mengatakan suatu keuntungan yang didapat setelah meninggalkan pekerjaan ranah publik dan menjadi ibu rumah tangga adalah dapat terlepas dari stress bekerja, tidak lagi menempuh perjalanan ke kantor dengan macetnya ibu kota yang menjadi beban tersendiri bagi informan. Oleh karena itu ia merasakan manfaat dan keuntungan yang diperoleh atas pilihannya menjadi ibu rumah tangga. Hal ini mengkonfirmasi dari Johnston \& Swanson, 2004 dalam (Pare dan Dillaway, 2005) yang melaporkan bahwa perempuan yang tadinya menjadi ibu rumah tangga mengalami perasaan tertekan atau stress ketika kembali ke ranah publik.

Sedangkan menurut informan AG, ia memilih meninggalkan karirnya dan menjadi Ibu Rumah Tangga karena menganggap anak sebagai aset di masa datang. Dalam wawancara bersama informan ia menyebutkan : 
"anak itu menurutku aset ku di masa datang yang harus dipersiapkan untuk menghadapi masa depannya nanti, hmm tapi bukan tentang uang ya dek, kali aja dari sekarang kita didik peka, sayang, perhatian ke orangtua, besok dia akan sayang dan perhatian juga sama kita ketika tua nanti"

(wawancara dengan Informan

AG, 22 oktober 2015)

Adapula informan berinisial RT yang mengaitkannya dengan norma agama ia mengungkapkan bahwa menjadi ibu rumah tangga adalah sebuah ibadah dan akan mendatangkan pahala.

"pasti kan kalau dari agama manapun mau ngurus anak dan suami wajib ya. pasti dari agama manapun pahalanya gede (wawancara dengan informan RT, 27 oktober 2015)

Pernyataan informan tersebut mengindikasikan bahwa keuntungan (reward) yang dipertimbangkan seseorang dalam pilihannya untuk mencapai tujuannya tidak selalu didasarkan pada hal kepuasan ekonomi seperti layaknya prinsip dasar teori pilihan rasional. Akan tetapi adapula pertimbangan dari kepuasan interaksi dalam hal ini interaksi antara ibu dan anak. selain itu melalui pernyataan tersebut mencoba melengkapi teori pilihan rasional yang telah ada sebelumnya, bahwa reward yang dianggap suatu keuntungan dan sebagai pemenuhan kepuasan seseorang tidak selalu terbatas pada kurun waktu saat ini saja melainkan keuntungan yang sifatnya waktu yang akan datang.

White and Klein (2000) memberikan definisi reward sebagai apapun yang diterima seseorang sebagai keuntungan. Berdasarkan paparan informan tersebut tercemin bahwa reward yang diperoleh ibu rumah tangga yang bergelar sarjana adalah terletak pada keluarga. Bagi mereka kestabilan fungsi keluarga merupakan keuntungan yang diperoleh dari pilihan menjadi ibu rumah tangga.

Akan tetapi keempat informan menjelaskan bahwa mereka tidak menyayangkan pendidikan yang telah dicapai tidak dipergunakan di sektor kerja publik. Salah satu informan berinisial VT mengatakan bahwa perempuan yang bekerja maupun menjadi ibu rumah tangga tetap harus berpendidikan tinggi karena perannya besar dalam mendidik anak.

Informan berinisial VT dan RT mengungkapkan bahwa ilmu yang telah dipelajari pada saat kuliah juga terpakai saat menjadi ibu rumah tangga. Informan VT menceritakan 
bahwa perkuliahan mengenai media massa membuat ia lebih aware lagi dan selektif dalam memilih tayangan televisi untuk anaknya. Informan berikutnya berinisial RT juga demikian bercerita bahwa ilmu farmasi yang didapat saat berkuliah masih dirasakan berguna oleh keluarganya, misalnya dalam menanyakan kegunaan obat dan bagaimana aturan mengkonsumsi suatu obat. Berdasarkan pengakuan informan tersebut hal ini merupakan suatu reward yang diperoleh dari lbu rumah tangga dengan gelar sarjana karena pada saat menjadi ibu rumah tangga perempuan tetap dapat mengaktualisasikan dirinya dengan mengaplikasikan ilmu yang telah diperoleh semasa kuliah ke dalam keluarga mereka

Cost yang harus dikeluarkan oleh perempuan sarjana yang memilih menjadi ibu rumah tangga adalah tidak lagi mendapat penghasilan tetap, mengalami kebosanan dengan pekerjaan domestik dan keterbatasan dalam berpergian dengan teman-teman. Dari keempat informan mengungkapkan bahwa ada kalanya mereka merasa bosan dan lelah dalam melakukan pekerjaan domestik. Setiap hari yang dikerjakan adalah memasak, membersihkan rumah, mengantar anak ke sekolah dan mendampingi anak bermain. keempat informan juga mengaku bahwa semenjak menjadi ibu rumah tangga, ia memiliki keterbatasan untuk melakukan aktivitas di luar rumah atau kalaupun pergi ke luar rumah misalnya untuk bertemu dengan teman-teman, ia harus mengajak anaknya untuk ikut. Seperti yang dipaparkan oleh salah satu informan berinisial DP yang menceritakan beban yang harus dijalani sebagai ibu rumah tangga

"ini sih suka merasa bosan
karna melakukan rutinitas
rumah tangga yang itu-itu saja,
kadang iri juga lihat teman-
teman yang belum menikah
sudah dijenjang karir yang
sekarang, bisa travelling
kemana mana, pendapatan
utama dari suami jadi dalam
mengelola kebutuhan lebih
mementingkan kebutuhan
keluarga daripada kebutuhan
pribadi.
(Wawancara dengan informan
DP, 7 Oktober 2015)

Selanjutnya cost yang berkaitan dengan relasi teman. Ketika berada di ranah publik, seseorang akan memiliki interaksi yang lebih luas dibandingkan ibu rumah tangga. Informan juga mengungkapkan bahwa semenjak memutuskan menjadi ibu rumah tangga, mereka 
tidak lagi memiliki kebebasan yang sama untuk bertemu dengan temantemannya. Akan tetapi, menurut informan hal tersebut bisa diatasi dengan adanya teknologi komunikasi, sehingga walaupun ibu rumah tangga tidak bekerja mereka tetap bisa menjalin relasi dengan temantemannya. Selain itu bagi ibu rumah tangga yang telah memiliki anak yang sudah bersekolah, modal sosial dengan rekan di tempat kerjanya bisa digantikan dengan rekan-rekan orang tua di sekolah anaknya. Seperti penjelasan informan, yang mengungkapkan :

"sekarang malah teman-
temannya ya dari sesama
orang tua di sekolah quinn, jadi
walaupun gak kerja juga bisa
tetap bersosialisasi dengan ibu
rumah tangga lain, di rumah,
dan sekolah." (Wawancara
dengan Informan AG,22
Oktober 2015)

Hal ini memberikan konfirmasi dengan tulisannya Giele (2008) yang membandingkan antara perempuan yang bekerja dan penuh waktu di rumah. Disebutkan bahwa dalam komunitas yang lebih luas, ibu berpendidikan tinggi yang modern cenderung menjadi outstanding networker karena ia membantu berpatisipasi dan mengorganisir dalam kelompok ibu-ibu di saat anak mereka sedang bermain.

Tabel 2. Kalkulasi Perempuan sarjana menjadi Ibu rumah tangga

\begin{tabular}{|c|c|c|c|c|}
\hline & VT & DP & RT & $A G$ \\
\hline $\begin{array}{l}\text { Co } \\
\text { st }\end{array}$ & $\begin{array}{l}\text { 1.Tid } \\
\text { ak } \\
\text { mend } \\
\text { apat } \\
\text { peng } \\
\text { hasil } \\
\text { an } \\
\text { tetap } \\
\text { 2.Har } \\
\text { us } \\
\text { lebih } \\
\text { disipli } \\
\mathrm{n} \\
\text { meng } \\
\text { atur } \\
\text { peng } \\
\text { eluar } \\
\text { an } \\
\text { kelua } \\
\text { rga } \\
\text { 3.Tid } \\
\text { ak } \\
\text { beba } \\
\text { s lagi } \\
\text { jalan- } \\
\text { jalan } \\
\text { deng } \\
\text { an } \\
\text { tema } \\
\mathrm{n}- \\
\text { tema } \\
\mathrm{n} \\
\text { kanto } \\
\mathrm{r}\end{array}$ & $\begin{array}{l}\text { 1.Tida } \\
\mathrm{k} \\
\text { menda } \\
\text { pat } \\
\text { pengh } \\
\text { asilan } \\
\text { tetap } \\
2 . \text { Kep } \\
\text { enting } \\
\text { an } \\
\text { meme } \\
\text { nuhi } \\
\text { keingi } \\
\text { nan } \\
\text { pribadi } \\
\text { dinom } \\
\text { orseki } \\
\text { ankan } \\
\text { (meng } \\
\text { utama } \\
\text { kan } \\
\text { kepent } \\
\text { ingan } \\
\text { keluar } \\
\text { ga } \\
3 \text {. } \\
\text { Terbat } \\
\text { asnya } \\
\text { kesem } \\
\text { patan } \\
\text { untuk } \\
\text { travelli } \\
\text { ng } \\
\text { atau } \\
\text { berper } \\
\text { gian }\end{array}$ & $\begin{array}{l}1 . \\
\text { Meng } \\
\text { alami } \\
\text { kebo } \\
\text { sana } \\
\mathrm{n} \\
\text { deng } \\
\text { an } \\
\text { peker } \\
\text { jaan } \\
\text { dome } \\
\text { stik } \\
2 . \text { Ter } \\
\text { batas } \\
\text { nya } \\
\text { untuk } \\
\text { pergi } \\
\text { bersa } \\
\text { ma } \\
\text { tema } \\
\mathrm{n}- \\
\text { tema } \\
\mathrm{n} \\
\text { 3.Tid } \\
\text { ak } \\
\text { mend } \\
\text { apat } \\
\text { peng } \\
\text { hasil } \\
\text { an } \\
\text { tetap. }\end{array}$ & $\begin{array}{l}\text { 1.Tid } \\
\text { ak } \\
\text { mend } \\
\text { apat } \\
\text { peng } \\
\text { hasila } \\
\mathrm{n} \\
\text { tetap } \\
\text { 2.Tid } \\
\text { ak } \\
\text { mend } \\
\text { apat } \\
\text { peng } \\
\text { hasila } \\
\mathrm{n} \\
\text { tetap }\end{array}$ \\
\hline $\begin{array}{l}R e \\
\text { wa } \\
r d\end{array}$ & $\begin{array}{l}\text { 1.Terl } \\
\text { epas } \\
\text { dari } \\
\text { stres } \\
\text { s } \\
\text { kema } \\
\text { cetan }\end{array}$ & $\begin{array}{l}1 . \\
\text { Memili } \\
\text { ki } \\
\text { waktu } \\
\text { banya } \\
\text { k } \\
\text { untuk }\end{array}$ & $\begin{array}{l}\text { 1.Da } \\
\text { pat } \\
\text { mend } \\
\text { ampi } \\
\text { ngi } \\
\text { masa } \\
\text { perke }\end{array}$ & $\begin{array}{l}\text { 1.Dap } \\
\text { at } \\
\text { mend } \\
\text { ampi } \\
\text { ngi } \\
\text { masa } \\
\text { perke }\end{array}$ \\
\hline
\end{tabular}




\begin{tabular}{|c|c|c|c|}
\hline $\begin{array}{l}\text { dala } \\
\mathrm{m} \\
\text { beker } \\
\text { ja } \\
\text { 2.Terl } \\
\text { epas } \\
\text { dari } \\
\text { konfli } \\
\text { k } \\
\text { relasi } \\
\text { di } \\
\text { peker } \\
\text { jaan } \\
3 . \text { Da } \\
\text { pat } \\
\text { mend } \\
\text { ampi } \\
\text { ngi } \\
\text { masa } \\
\text { perke } \\
\text { mban } \\
\text { gan } \\
\text { anak } \\
4 . M e \\
\text { miliki } \\
\text { wakt } \\
\text { u } \\
\text { yang } \\
\text { lebih } \\
\text { fleksi } \\
\text { bel } \\
5 . r u m \\
\text { ah } \\
\text { menj } \\
\text { adi } \\
\text { lebih } \\
\text { tertat } \\
\text { a }\end{array}$ & $\begin{array}{l}\text { memp } \\
\text { erhatik } \\
\text { an } \\
\text { orang } \\
\text { tua } \\
\text { dan } \\
\text { adik } \\
2 \text {. } \\
\text { Memili } \\
\text { ki } \\
\text { quality } \\
\text { time } \\
\text { bersa } \\
\text { ma } \\
\text { keluar } \\
\text { ga inti } \\
3 . \\
\text { Memili } \\
\text { ki } \\
\text { relasi } \\
\text { yang } \\
\text { dekat } \\
\text { denga } \\
\text { n anak } \\
4 . \\
\text { Secar } \\
\text { a } \\
\text { perhitu } \\
\text { ngan } \\
\text { ekono } \\
\text { mi } \\
\text { lebih } \\
\text { mengu } \\
\text { ntungk } \\
\text { an } \\
5 . \\
\text { Bain } \\
\text { Belajar } \\
\text { lebih } \\
\text { mandir } \\
\text { i dan } \\
\text { tidak } \\
\text { lagi } \\
\text { bergan } \\
\text { tung } \\
\text { pada } \\
\text { orang }\end{array}$ & $\begin{array}{l}\text { mban } \\
\text { gan } \\
\text { anak } \\
2 . \\
\text { Anak } \\
\text { menj } \\
\text { adi } \\
\text { lebih } \\
\text { dekat } \\
\text { deng } \\
\text { an } \\
\text { diriny } \\
\text { a } \\
3 . \text { Me } \\
\text { ngan } \\
\text { ggap } \\
\text { bahw } \\
\text { a } \\
\text { mend } \\
\text { apat } \\
\text { pahal } \\
\text { a dari } \\
\text { Tuha } \\
\text { n } \\
4 . M e \\
\text { miliki } \\
\text { bany } \\
\text { ak } \\
\text { wakt } \\
\text { u } \\
\text { untuk } \\
\text { berso } \\
\text { sialis } \\
\text { asi } \\
\text { deng } \\
\text { an } \\
\text { tetan } \\
\text { gga } \\
5 . \\
\text { Memi } \\
\text { liki } \\
\text { wakt } \\
\text { u } \\
\text { yang } \\
\text { lebih } \\
\text { fleksi } \\
\text { bel }\end{array}$ & $\begin{array}{l}\text { mban } \\
\text { gan } \\
\text { anak } \\
2 . \text { Ana } \\
\mathrm{k} \\
\text { menj } \\
\text { adi } \\
\text { lebih } \\
\text { dekat } \\
\text { deng } \\
\text { an } \\
\text { diriny } \\
\text { a } \\
3 \text {. } \\
\text { Memil } \\
\text { iki } \\
\text { bany } \\
\text { ak } \\
\text { waktu } \\
\text { untuk } \\
\text { meny } \\
\text { alurk } \\
\text { an } \\
\text { hobi } \\
\text { mem } \\
\text { asak } \\
4 . \text { Ber } \\
\text { sosial } \\
\text { isasi } \\
\text { deng } \\
\text { an } \\
\text { orang } \\
\text { tua } \\
\text { murid } \\
\text { di } \\
\text { sekol } \\
\text { ah } \\
\text { anak } \\
\text { nya } \\
5 . \\
\text { Mera } \\
\text { sa } \\
\text { lebih } \\
\text { ungg } \\
\text { ul } \\
\text { diban } \\
\text { dingk } \\
\text { an } \\
\text { deng } \\
\text { an }\end{array}$ \\
\hline
\end{tabular}

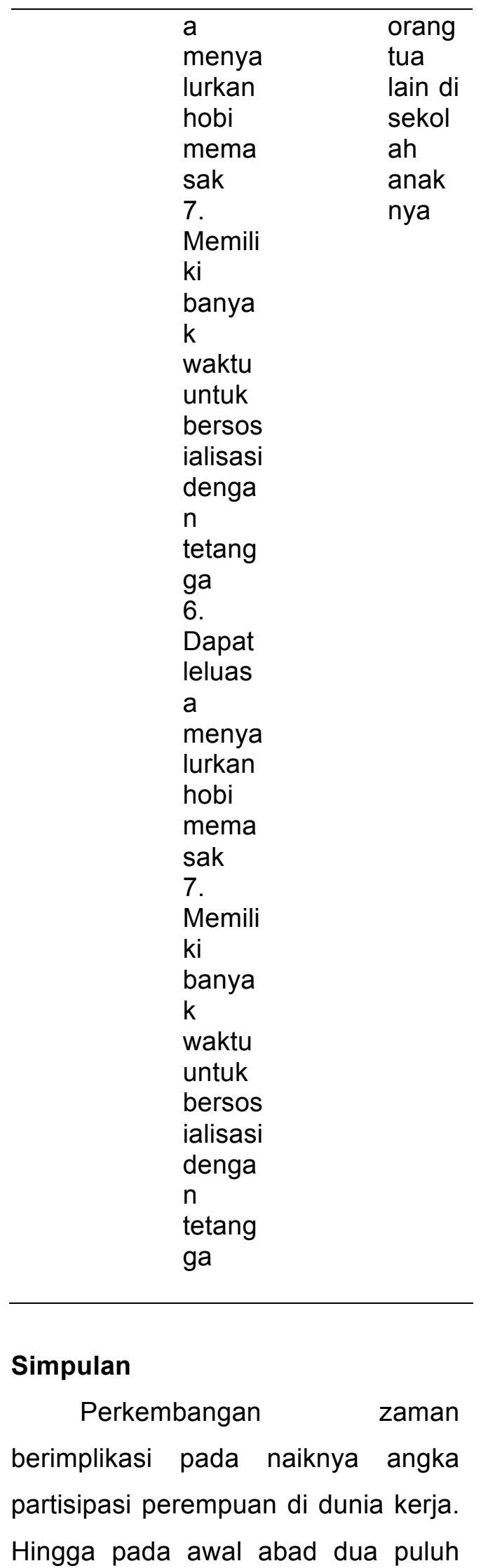


terus terjadi kenaikan presentase perempuan yang berkiprah ke ranah publik dan tidak lagi menguasai ranah domestik saja. Akan tetapi dalam artikel ini mencoba mengulas kembalinya fenomena domestikasi pada perempuan. Berangkat dari penurunan angka partisipasi kerja wanita di Indonesia, artikel ini membahas perempuan sarjana yang memutuskan untuk meninggalkan karir dan menetapkan pilihan sebagai lbu rumah tangga penuh waktu. Melengkapi penelitian sebelumnya yang membahas faktor eksternal dalam keputusan perempuan sarjana menjadi Ibu Rumah Tangga, artikel ini menunjukan proses internal dari keputusan perempuan sarjana menjadi Ibu rumah tangga. Secara kalkulasi reward dan cost yang diperoleh perempuan sarjana sebagai Ibu rumah tangga, memperlihatkan adanya sebuah pilihan rasional dari ibu rumah tangga berpendidikan tinggi. reward yang diterima oleh ibu rumah tangga terdidik diantaranya, terlepas dari stress bekerja, efektif dalam pengasuhan anak, penghematan biaya dalam mengurus anak, memiliki waktu yang fleksibel, dan menjadi lebih mandiri, serta mengaktualisasikan diri kepada hobi.
Sedangkan cost yang dikeluarkan antara lain mengorbankan kebutuhan materi pribadi, merasa bosan dengan rutinitas dan berkurangnya frekuensi bersosialisasi dengan teman.

Dalam proses pengambilan keputusan menjadi ibu rumah tangga, seorang perempuan berpendidikan tinggi sekalipun selalu dihadapkan dengan faktor eksternal seperti nilai masyarakat, dorongan suami dan orangtua hingga distrust dengan jasa baby sitter. Keputusan perempuan sarjana menjadi ibu rumah tangga memang lekat dengan kondisi-kondisi sosial akan tetapi dengan analisa comparison level dan comparison alternative dapat dinyatakan bahwa keputusan tersebut merupakan pilihan rasional. berdasarkan keempat kasus, ibu rumah tangga bergelar sarjana memiliki nilai lebih dalam memberikan orientasi pendidikan dan pengasuhan bagi anak dibandingkan ibu rumah tangga yang tidak berpendidikan tinggi dan berdasarkan analisa comparison alternative, dengan kalkulasi cost dan reward ibu rumah tangga berpendidikan tinggi merasa lebih beruntung dibandingka ibu rumah tangga yang menjalankan peran ganda. 


\section{Ucapan Terima Kasih}

Terima kasih kepada semua pihak yang telah mendukung penulisan artikel ini. Selanjutnya kami ucapkan terima kasih kepada redaksi Jurnal Dimensia yang telah menerbitkan tulisan ini.

\section{Daftar Pustaka}

Goode, William J. 1995. Sosiologi Keluarga. Jakarta : Bumi Aksara

Klein, David and James White. 2002. Family Theories. United States: Sage Publication

Ritzer, George. 2008. Teori Sosiologi. Bantul: Kreasi Wacana

Giele, Janet Zollinger. 2008. Homemaker or Career Woman: Life Course Factors and Racial Influences among Middle Class Americans

Kitterod dan Ronsen. 2011. Housewives in a dual-earner society Who is a housewife in contemporary Norway?. Statistics Norway, Research Department

Miller,2013. The Retro Life : Feminists who says they're having it all- by choosing to stay home

Haque,M.Syamsul. 2010. Representation of women in governance in Singapore: Trends and problems. Asian Journal of Political Science. National University of Singapore Vol 8 No. $259-87$

Bruce, J. Llyod, C,B, Leonard. 1995. Families focus, a new perspectives on mothers, fathers, and children. The Population Council.

Monroe, Kristen. 2001. Paradigm
Shift: From Rational Choice to Perspective.

International Political Science Review (2001), Vol 22, No. 2, 151-172

Pare, Elizabeth and Heather Dillaway. 2005. Staying at Home" versus "Working": A Call for Broader Conceptualizations of Parenthood and Paid Work. Michigan Family Review, 10, 6687,2005

Scott, John. 2000. From Understanding Contemporary Society: Theories of The Present Rational Choice Theory. Sage Publications

Watanabe, Megumi. 2007. Japanese Middle-aged Women's Careers after Leaving their Jobs for Marriage and Childbirth. JSPS Research Fellow, Hitotsubashi University

Working Mother Research Institute. 2011. What Moms Choose: The Working Mother Report

Profil Perempuan Indonesia, http://www.kemenpppa.go.id/inde x.php/data-summary/profileperempuan-indonesia/634ketenagakerjaan

Tingkat Partisipasi Angkatan Kerja Nasional, http://www.bps.go.id/kependuduk an/Pages/DataSurvey/Sakernas/ Ekonomi_dan_Ketenagakerjaan/ TPAK/Nasional.aspx

Wang, Wendy dkk. 2014. After Decades of Decline, A Rise in Stay-at-Home Mothers http://www.pewsocialtrends.org/2 014/04/08/after-decades-ofdecline-a-rise-in-stay-at-home- 